Original Contribution

\title{
MN AND ZN CONTENT IN EGGS AND MUSCULATURE OF RAINBOW TROUT (ONCORHYNCHUS MYKISS W.) TREATED WITH FUNGICIDE MANCOZEB AND PIGMENT ASTAXANTHIN
}

\author{
E. Valkova*, V. Atanasov, M. Tzanova, S. Denev \\ Department of Biochemistry, Microbiology and Physics, Faculty of Agriculture, Trakia University, \\ Stara Zagora, Bulgaria
}

\begin{abstract}
The present study aims to determine the levels of the heavy metals manganese (Mn) and zinc ( $\mathrm{Zn}$ ) contained in the fungicide Mancozeb in the eggs and musculature of the rainbow trout (Oncorhynchus mykiss W.) which have grown in an environment, containing a permissible amount of Mancozeb and fed with or without the carotenoid pigment astaxanthin. The study follows the feeding, then the analysis of the level of $\mathrm{Mn}$ and $\mathrm{Zn}$ in the eggs and musculature of the rainbow trout, treated with and without the pigment astaxanthin and the fungicide Mancozeb. The determination of $\mathrm{Mn}$ and $\mathrm{Zn}$ concentrations is performed using a modern method for measuring macro- and microelements with an atomic absorption spectrometer, which is characterized by high selectivity, swiftness and sensitivity. Experimental data show accumulation of $\mathrm{Mn}$ and $\mathrm{Zn}$, contained in the fungicide Mancozeb even when its concentration in the habitat does not exceed the maximum permissible levels in the normative documents. As a result, the analysis of the eggs and musculature shows the same trend regarding the accumulation of $\mathrm{Mn}$ and $\mathrm{Zn}$. In non-fertilized, as well as in fertilized rainbow trout eggs and musculature, the experimental data show a slight increase of $\mathrm{Mn}$ and $\mathrm{Zn}$ in the presence of only astaxanthin in the added feed and a significant decrease in these metals in the presence of both astaxanthin and Mancozeb. The supplementation of astaxanthin in the diet can significantly reduce the rate of heavy metals accumulation in fish tissues and eggs, but high concentrations of these pollutants in the aquatic environment over a longer period of time would certainly result in metabolic disturbances in the fish body and reduction of their eggs' hatchability.
\end{abstract}

Keywords: Rainbow trout; Mancozeb, Astaxanthin, Heavy metals; Eggs, Musculature.

\section{INTRODUCTION}

The cross-application of pesticides in agriculture for eliminating crop pests is the cause of their leading role in environmental pollution. Pesticides and their metabolites are characterized by horizontal and vertical migration into the soil through rain and irrigation water from where they penetrate into groundwater (1). These toxicants, which have entered the water basins, have the ability to squeeze into the hydrobionts and to exert their effect, causing undesirable metabolic changes. Even low levels of pesticides can cause disorientation in the choice of food and habitat

\footnotetext{
*Correspondence to: Elica Valkova, Department of Biochemistry, Microbiology and Physics, Faculty of Agriculture, Trakia University, Studentski grad, 6000, Stara Zagora, Bulgaria, Elica_Valkova@abv.bg
}

in fish (2-6). Pollutants of this nature are often lead to the reduction of the immune protection of aquatic organisms. A condition known as M74 (7) which involves a decrease in habitability of eggs, yolk outflow and early mortality in salmon fish has been observed. The presence of toxicants in water for aquaproduction can be eliminated with farming of fish in recirculation systems (8-11). High purification effect during intensive growing of different species uses $C$. vulgaris for biological treatment of water $(9,12)$. There are many other alternative methods of water treatment, which ensure the development of sustainable aquaculture $(9,13,14)$.

The Commission Directive 2005/72/EC (15) defines Mancozeb as fungicide, which is a polymer blend of $\mathrm{Zn}$ and Mn-ethylene dithiocarbamates. According to our research, 
the metabolic product of this fungicide ethylene thiourea - does not accumulate in large quantities in the organism and the eggs and does not have a toxic effect even after prolonged treatment of adult individuals of salmonid fish (16). As for concentrations of $\mathrm{Mn}$ and $\mathrm{Zn}$ contained in the mentioned fungicide, their accumulation has been observed even after the use of acceptable amounts of Mancozeb as treatment. This is most likely due to the ability of Salmonidae to accumulate heavy metals over time and serve as excellent bioindicators for contamination (17-19).

It was found that the heavy elements are accumulated primarily in the liver, musculature and eggs of fish. Heavy metals such as $\mathrm{Cd}, \mathrm{Cr}$, $\mathrm{Fe}, \mathrm{Mn}, \mathrm{Pb}, \mathrm{Mg}, \mathrm{Hg}$, $\mathrm{Mo}, \mathrm{Ag}$ and $\mathrm{Zn}$, in the form of ions easily enter the larvae and the eggs (20-27), causing reduction of the rate of formation of the vertebral column, growth, metabolism and absorption of the yolk and the water-mineral and acid-alkaline balance by inhibiting the activity of the ion pump in the gills or epithelium of the yolk bubble. The sensitivity of eggs depends on the duration of the impact (21).

Mn, as an important biogenic element, realizes its biochemical role by participating as a cofactor in enzymes such as arginase, superoxide dismutase and pyruvate carboxylase (28). It contributes to the maintenance of the nervous and the immune system and the regulation of blood sugar.

Excessive rise in Mn levels in aquatic invertebrates and fish leads to a significant reduction in the number of red and white blood cells and the amount of hemoglobin. Reduction of red blood cells and hematocrit is due to internal bleeding, possibly due to necrosis of the intestinal mucosa and kidneys (29).

Low doses of $\mathrm{Zn}$ are needed to maintain cell membrane integrity, bone mineralization and wound healing. High concentrations of $\mathrm{Zn}$ in fish (trout) leads to structural changes in the main classes of lipids and a number of enzyme proteins (30), a decrease in the activity of ceruloplasmin as well as necrosis of the liver tissue (1).

Hydrobionts, especially salmon fish, are extremely sensitive to environmental pollution. These organisms also react to the smallest deviations in heavy metal levels and are therefore used as bio indicators for water contamination $(31,32)$.

Trout family are a particularly preferred product on the fish market as they are safe and high quality food containing valuable ingredients such as unsaturated fatty acids, vitamins and complete proteins.

These aquatic species have the ability to accumulate heavy metals in their tissues in levels, thousands of times higher than those in the surrounding water environment. Often, the quantities of these elements in water are within the permissible limits, but over time the concentration in the fish body significantly exceeds the admissible levels. Pigments such as astaxanthin and canthaxanthin, added in certain quantities, can significantly reduce the accumulation and impact of heavy metals in the body of these fish species (33). In view of these facts, further research is needed.

The aim of this study is to determine the levels of heavy metals $\mathrm{Mn}$ and $\mathrm{Zn}$ contained in the pesticide Mancozeb in the eggs and musculature of the rainbow trout (Oncorhynchus mykiss W.) grown in environment containing a quantity of Mancozeb eligible under the European legislation with/without astaxanthin pigment. юThe implementation of the above mentioned aim requires us to find out whether limited concentration of Mancozeb can lead to the accumulation of $\mathrm{Mn}$ and $\mathrm{Zn}$ in the rainbow trout eggs and musculature, which can be hazardous to human consumers.

\section{MATERIALS AND METHODS Experimental period and fish collection}

The study was conducted in 2015 and included the following steps: feeding and analysis of the content of heavy metals $\mathrm{Mn}$ and $\mathrm{Zn}$ in the eggs and musculature of the rainbow trout (Oncorhynchus mykiss W.) with and without treatment with the carotenoid pigment astaxanthin and the fungicide Mancozeb. Fishes with a body weight of $915 \pm 23$ g were divided into four groups - untreated, treated with Mancozeb, treated with astaxanthin and treated with both Mancozeb and astaxanthin. Rainbow trout farming took place in a Bulgarian fish farm near the Tundzha River and Sredna Gora. The qualitative and quantitative parameters of the water used for the breeding of the fish species complied with Regulation № 44 (34). The waters of Tundzha 
River were used as a water source. Their temperature varied from $4.2^{\circ} \mathrm{C}$ to $19.8^{\circ} \mathrm{C}$ and dissolved oxygen from $9.1 \mathrm{mg} . \mathrm{I}^{-1}$ to $10.8 \mathrm{mg} . \mathrm{I}^{-}$ 1 depending on the season and the time of sampling during the day.
VALKOVA E., et al.

The fish were fed with specialized extruded fodder AQUA ECO (Austria). The carotenoid pigment astaxanthin was provided through a specialized granulated fodder "AQUA PROFI PIGMENT" of the company "AQUA GARANT" - Austria with the following ingredients: Table 1, (35).

Table 1. Composition of specialized fodder for salmon fish "AQUA PROFI PIGMENT"

\begin{tabular}{|l|l|}
\hline Declared content / kg & $\mathbf{4} \mathbf{~ m m ~} \mathbf{6} \mathbf{~ m m}$ \\
\hline Crude protein & $42 \%$ \\
\hline Crude fat & $23,5 \%$ \\
\hline Crude fibers & $2,2 \%$ \\
\hline Phosphorus & $1,20 \%$ \\
\hline Vitamin A & 10000 I.E. \\
\hline Vitamin $\mathrm{D}_{3}$ & $1500 \mathrm{I} . \mathrm{E}$. \\
\hline Vitamin E & $200 \mathrm{mg}$ \\
\hline Digestible energy & $20,8 \mathrm{MJ}$ \\
\hline Cantxanthin & $25 \mathrm{mg}$ \\
\hline Astaxanthin & $40 \mathrm{mg}$ \\
\hline
\end{tabular}

Mancozeb was added daily to the water for 60 feeding days in quantities leading to a final concentration of $0.5 \mu \mathrm{g} . \mathrm{l}^{-1}$, meeting the requirements of Regulation № 9 of the Bulgarian Ministry of the Environment (36) and Water and Directive 2000/60/EC of the European Parliament (37). In females that were used for the analysis, the feeding started on $1^{\text {st }}$ September and ended on $1^{\text {st }}$ November, 2015.

Samples storage and determination of quantities of heavy metals $\mathrm{Mn}$ and $\mathrm{Zn}$ and pigment astaxanthin

Biological material for the analysis of the heavy metals $\mathrm{Mn}$ and $\mathrm{Zn}$ and astaxanthin in eggs and musculature was obtained from all batches on December 1 ${ }^{\text {st }}, 2015$.

When working with fish, the requirements of Ordinance №20 of 01.11.2012 on the minimum requirements for the protection and humane treatment of experimental animals and the requirements for the use, breeding and / or delivery within the Bulgarian legislation were met. The animals were not exposed to unnecessary pain or suffering.

The samples were immediately frozen after collection, transported to a refrigerator and stored for a maximum of 14 days at $12^{\circ} \mathrm{C}$ before the analysis.

The preparation of the biological samples for determining of the tested heavy metals was carried out by mineralization in a mixture of 1 $\mathrm{ml}$ concentrated $\mathrm{HCl}$ and $6 \mathrm{ml}$ concentrated $\mathrm{HNO}_{3}$ acids.

The determination of concentrations of the heavy metals $\mathrm{Mn}$ and $\mathrm{Zn}$ concentrations was performed on an atomic spectrometer Perkin Elmer (AAS-GF-Analist 800).

The determination of the concentration of astaxanthin in the samples was made according to the procedure described by Tzanova et al. (2018) (38) and Tzanova, (2017) (16).

\section{Statistical methods}

The statistical analyses were performed with Statistica 6.1 (Statistics for Windows, Stat Soft Inc., USA) using an ANOVA test.

\section{RESULTS}

The accumulation of these elements can be significantly reduced by adding the xanthophyll pigment astaxanthin (39) to the feed. These compounds are powerful antioxidants that determine the color of the musculature and eggs in salmonids (40-42).

It has been shown that the presence of these carotenoids in the egg leads to an increase of egg fertility, lower fetal mortality, so that the fry obtained do not suffer from reproductive syndrome M74, even at the risk of this disease $(7,38)$. The addition of synthetic astaxanthin to food not only prevents the development of M74 but also improves the organoleptic qualities of trout (salmon trout), which also leads to an increase in consumers' interest (43). 
The levels of the heavy metals $\mathrm{Mn}$ and $\mathrm{Zn}$ contained in the above-mentioned fungicide which has been studied in the rainbow trout eggs and musculature can be influenced by the presence of the antioxidant astaxanthin in food. Changes in the concentrations of these metals either when this pigment is present or absent in rainbow trout eggs and musculature are illustrated in Figures 1, 2, 3 and 4.
VALKOVA E., et al.

The results listed in Figure 1 show that the nonfertilized eggs of salmonids contain twice as many $\mathrm{Mn}$ as the fertilized caviar of the same fish species. A number of studies worldwide prove the same trend - higher sensitivity to pollutants in non-fertilized fish eggs, compared to fertilized (44).

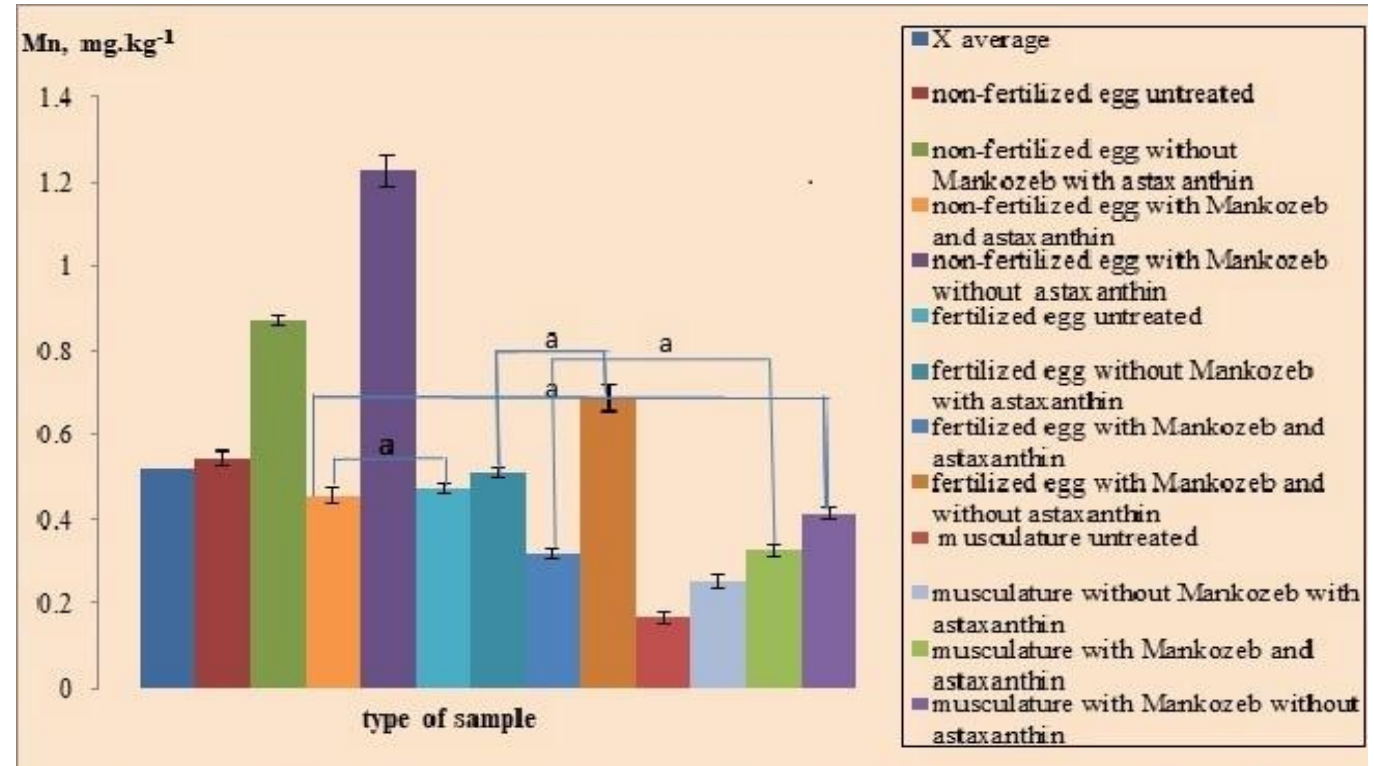

Figure 1. Mn content in eggs and musculature of rainbow trout fed with fodder with or without astaxanthin and Mancozeb ( $\mathrm{a}$ - There is no statistically significant difference between these variants, $\mathrm{p}>0.05$ ).

Data which refer to the change in manganese concentrations in the presence or absence of the pigment astaxanthin, as well as the changes in its levels in these situations, are given in Figure 2.
Data show that the increase of astaxanthin by adding it to trout food, leads to a decrease of $\mathrm{Mn}$ accumulation in musculature, which is an important economic, ecological and social aspect.

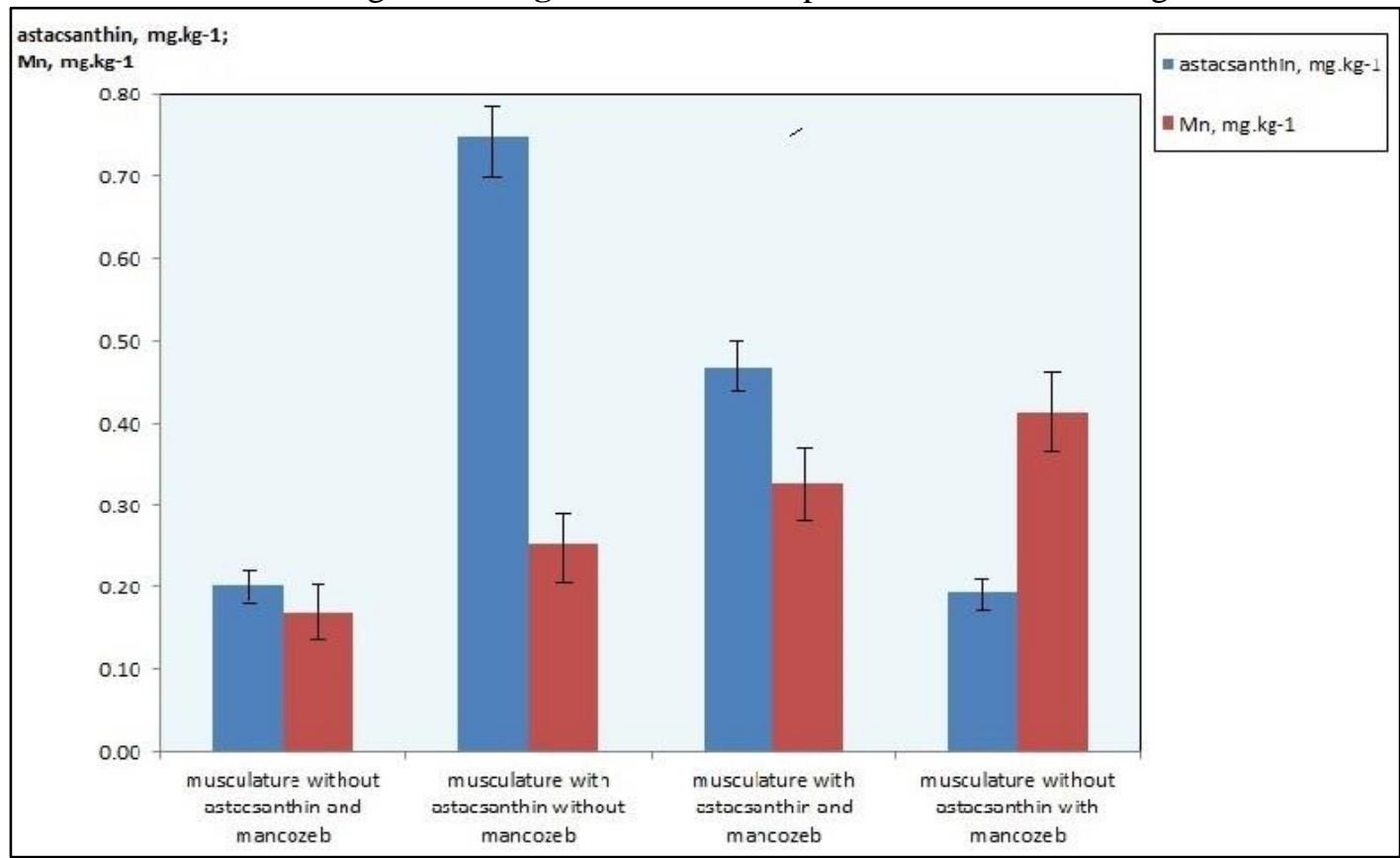

Figure 2. Mn and astaxanthin content in rainbow trout musculature, fed with fodder with or without astaxanthin and Mancozeb. 
$\mathrm{Zn}$ levels measured in the egg and musculature of the same trout species (Figure 3) prove a similar trend regarding the accumulation of heavy metals with and without the presence of astaxanthin and Mancozeb in the aquatic environment and food. In non-fertilized eggs, as well as in fertilized eggs and the musculature of rainbow trout, the
VALKOVA E., et al. reported data show a slight increase of zinc in the presence of only astaxanthin in the added feed and a significant decrease of that metal in the presence of astaxanthin and Mancozeb. This trend is explained by the presence of the studied biogenic element in the diet.

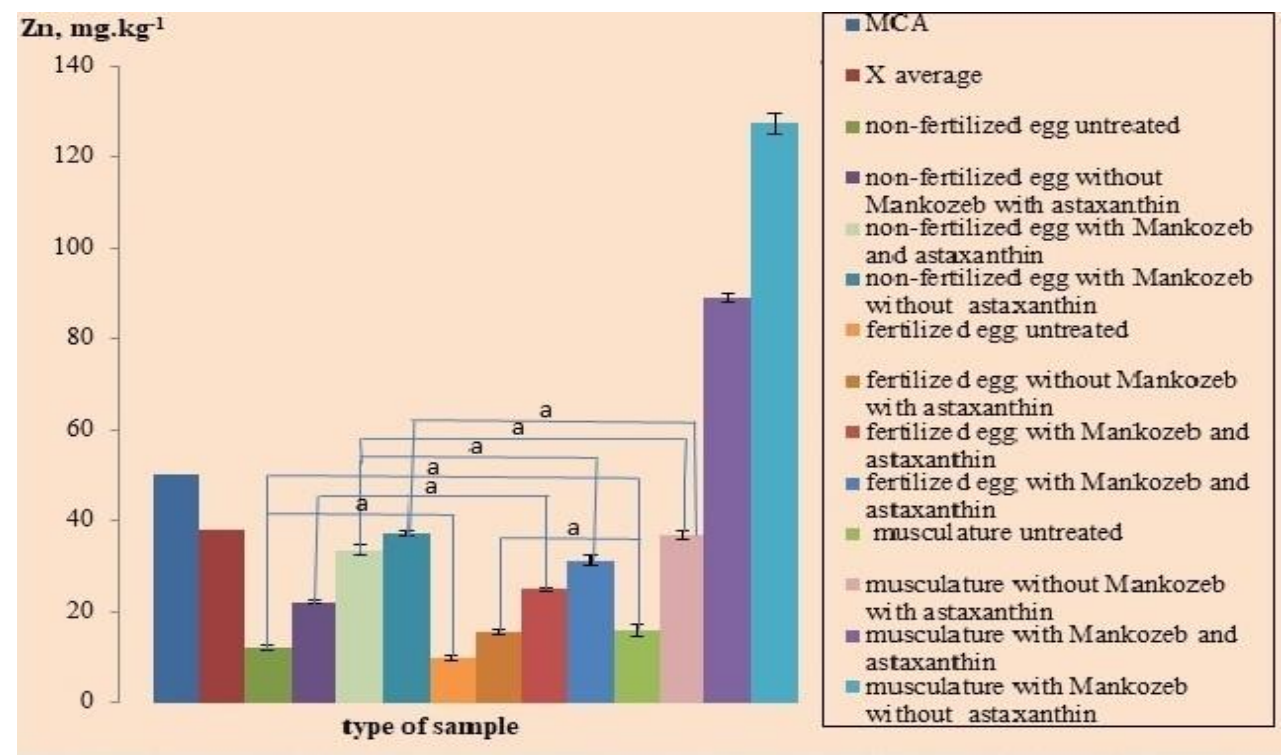

Figure 3. Zn content in egg and musculature of rainbow trout fed with fodder with or without astaxanthin and Mancozeb ( $\mathrm{a}$ - There is no statistically significant difference between these variants, $\mathrm{p}>0.05$ ).

The data regarding the levels of $\mathrm{Zn}$ in the musculature of trout versus those of astaxanthin (Figure 4) during the periods of feeding, with and without the presence of the pigment and the pesticide, indicate clearly the impact of astaxanthin on the ability to accumulate heavy metals in the fish organism. The studied antioxidant significantly reduces the zinc concentration, although it exceeds the requirements set by the normative documents.

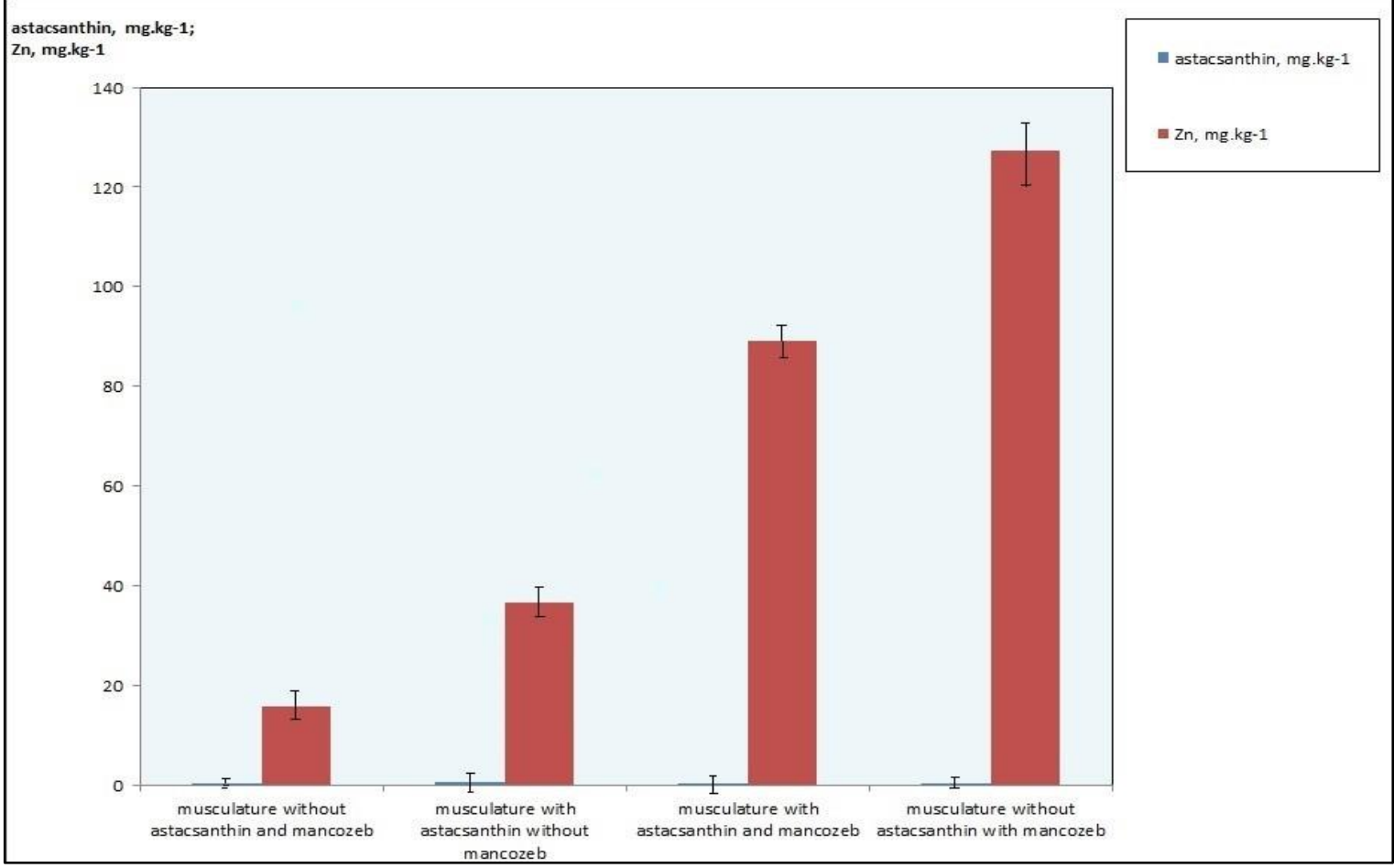

Figure 4. Zn and astaxanthin content in rainbow trout musculature, fed with fodder with or without astaxanthin and Mancozeb. 


\section{DISCUSSION}

Hydrobionts such as Salmonidae are often exposed to various types of toxicants such as pesticides and their metabolites, chlorine compounds, heavy metals and others. Some of these agents can act not only through their metabolic products, but also through the heavy elements contained in them. This is also the case with the fungicide Mancozeb, which can exert its toxic effect by incorporating the heavy metals $\mathrm{Mn}$ and $\mathrm{Zn}$ into the water basins which are the living environment for trout.

Analysis relating to manganese content in the musculature of treated salmonids clearly shows the protective role of astaxanthin in the presence of Mancozeb in the growing habitat. The presence of this power antioxidant significantly reduces the accumulation and consequent negative effects of Mancozeb.

The obtained data show a certain increase in manganese levels relative to the mean value in both egg types with only astaxanthin in the middle. This result can be explained by the way untreated breeders are grown. They inhabit vast earth basins and consume the natural food base (larvae, arthropods, mollusks and fish). The highest manganese value significantly exceeding the calculated arithmetic mean is measured in egg samples treated with Mancozeb only $\left(1.23 \mathrm{mg} \cdot \mathrm{kg}^{-1}\right)$. Significantly higher concentrations of $\mathrm{Mn}$ in the eggs treated only with the studied pesticide compared to astaxanthin and Mancozeb have been observed simultaneously. The presence of the antioxidant has led to a decrease in the accumulation of manganese in both eggs types. The obtained result confirms the thesis of reducing the accumulation and impact of heavy metals and other toxicants in the presence of xanthophylls like astaxanthin in feed of farmed fish. Most of the established values of the four sample types are below the calculated average of $\mathrm{Zn}$ for the whole analysis, and below maximum permissible norms for content of this metal in this species of fish (45). The levels of this heavy metal registered in nonfertilized egg treated with Mancozeb are slightly below the determined average for the entire sampling period. The mean and maximum permissible values exceed the norms in samples taken from rainbow trout musculature treated with astaxanthin and Mankozeb or Mankozeb only.

As a result of the study, accumulation of zinc in the muscles was found to be above the
VALKOVA E., et al. regulatory requirements $\left(50 \mathrm{mg} \cdot \mathrm{kg}^{-1}\right)(45,46)$, which indicates an overtime accumulation of this element, even with the use of Mancozeb in permissible concentrations. The established levels of this heavy metal in the musculature are a cause of concern, because this part of the fish is mainly used for human consumption. It turns out that it is possible to accumulate $\mathrm{Zn}$ in the fish body, even when using this fungicide within normal limits, due to the penetration of its metabolites and heavy metals into the groundwater and the water basins where aquatic organisms find their natural habitat.

Zinc renders a higher toxicity on aquatic organisms compared to manganese, which is why the regulations do not set any limits for the $\mathrm{Mn}$ content in food. This study has therefore established the particular presence of abnormal levels of zinc.

The results of the study prove the ability of Salmonids to accumulate heavy metals in their tissue of levels several times higher than those in the surrounding aquatic environment, even when the quantities of these elements in the waters are within the permissible norms. The recorded data indicates an accumulation of heavy metals $\mathrm{Mn}$ and $\mathrm{Zn}$ contained in the fungicide Mankozeb even when its concentration in the environment does not exceed the maximum permitted levels in the normative documents.

The concentrations of $\mathrm{Mn}$ and $\mathrm{Zn}$, registered in salmonids' non-fertilized egg are significantly higher than those in the fertilized egg of the same type of fish. The probable reason for this result is the way of growing untreated breeders. They inhabit extensive ground basins and consume the natural food base. Highest Mn values $\left(1.23 \mathrm{mg} \cdot \mathrm{kg}^{-1}\right)$ have been found in non-fertilized eggs samples treated with Mankozeb, while a maximum $\mathrm{Zn}$ concentration has been measured in the musculature samples treated with Mankozeb.

As a result of the analysis of the $\mathrm{Mn}$ and $\mathrm{Zn}$ levels in rainbow trout eggs and musculature, one and the same tendency has been observed regarding the accumulation of these heavy metals. In non-fertilized rainbow trout eggs, as well as in fertilized rainbow trout eggs and musculature, the reported data show a slight increase in manganese and zinc in the presence of only astaxanthin in the added food and a significant decrease in these metals in the presence of both astaxanthin and Mancozeb. 
This trend is explained by the fact that trout food contains the studied biogenic elements. The obtained result confirms the thesis of reducing the accumulation and impact of heavy metals and other toxicants in the presence of xanthophyll, like astaxanthin in the feed of farmed fish. Adding astaxanthin to the diet can significantly reduce the speed of heavy metal accumulation in fish tissues and eggs, but the presence of high concentrations of these pollutants in the aquatic environment over a prolonged period of time will undoubtedly result in metabolic disturbances in the fish body and decrease in the hatchability of their eggs. The obtained results prove the exceptional sensitivity of salmon fish that react to even the smallest changes in the levels of heavy metals, which makes them excellent indicators for pollution of freshwater and saltwater basins.

\section{CONCLUSION}

The supplementation of astaxanthin in the diet can significantly reduce the rate of heavy metals accumulation in fish tissues and eggs, but high concentrations of these pollutants in the aquatic environment over a long period of time would certainly result in metabolic disturbances in the fish body and reduction of their eggs hatchability.

\section{ACKNOWLEDGMENTS}

This research did not receive any specific grant from funding agencies in public, commercial, or non-profit sectors.

\section{AUTHOR CONTRIBUTIONS}

VA, SD and EV designed the study, EV and MT collected and analyzed all data, SD and GB performed statistical analyses. All authors approved final version of manuscript.

\section{CONFLICT OF INTEREST DISCLOSURE}

All authors of the present paper confirm no actual or potential conflicts of interest, including any financial, personal, or other relationships with people or organizations.

Piquette-Miller, M. and Jamali, F., Influence of severity of inflammation on the disposition and interaction with ketoprofen of propranolol enantiomers in adjuvant arthritis. Drug Metab Dispos, 23:240-245, 1985.

\section{REFERENCES}

1. Atanasov, V., Staykov, Y., Petkov, G., Hydrobionts. In: Manual book of metals Similar applied ecology", Eds.Ts.
VALKOVA E., et al.

Yablanski and G. Petkov, Alfamarket, Stara Zagora, Bulgaria.; 139-153, 2011.

2. Atanasoff, A., Nikolov, G., Staykov, Y., Zhelyazkov, G., Sirakov, I., Proximate and mineral analysis of atlantic salmon (Salmo salar) cultivated in Bulgaria. Biotechnol. in anim. Husbandry, 29 (3): 571-579, 2013.

3. Lind, P., Pesticides Threaten Salmon, Pesticides and You Beyond Pesticides. National Coalition Against th Misuse of Pesticides, Vol. 22, No. 1: 9 -10, 2002.

4. Mason, R., Tennekes, H., Sanchez-Bayo, F., Jepsen, P., Immune Suppression by Neonicotinoid Insecticides at the Root of Global Wildlife Declines. Journal of Environmental Immunology and Toxicology, 1:1, 3-12, 2013.

5. Stoyanova, S., Staykov, Y., Gelqzkov, G., Sirakov, I., Nikolov, G., Fish production and some traits of meat quality in rainbow trout (Oncorhynchus mykiss) farmed in different production systems. Agric. Sci. and Technol, vol. 8, 4: 346-350, 2016.

6. Zhelyazkov, G., Georgiev, D., Dospatliev, L., Staykov, Y., Determination of Heavy Metals in Roach (Rutilus rutilus) and Bleak (Alburnus alburnus) in Zhrebchevo Dam Lake. Ecologia Balkanica, vol. 5, Special Edition: 15-20, 2014.

7. Atanasov, V., Tzanova, M., Valkova, E., Krastev, B., Dimitrov, Zh., Ecologybiochemical aspects of the reproductive syndrome M74 in salmonids. Agricult. Sci., 52(2): 63-77. Available at: http://www.agris.fao.org/agrissearch/search.do?recordID=BG2015007427 [Accessed 26 June 2016], 2015.

8. Sirakov, I., Velichkova, K., Stoyanova, S., Comparison of microbiological parameters in experimental and conventional recirculation aquaculture systems. $J$. of Applied Biol. and Biotechnol., 3, 01: 021023, 2015.

9. Sirakov, I., Velichkova, K., Stoyanova, S., Dinev, D., Staykov, Y., Application of Natural Zeolites and Macrophytes for Water Treatment in Recirculation Aquaculture Systems. Bulg. J. Agric. Sci., Supplement 1, 21: 147-153, 2015.

10.Zhelyazkov, G., Effect of the linseed and sunflower oils in the diet on the growth parameters in rainbow trout (Oncorhynchus mykiss $W$.), cultivated in recirculating system. Agric. Sci. and Technol., vol. 6, (4): 431 - 436, 2014.

11.Zhelyazkov, G, Popova, T., Staykov, Y., Effect of sunflower and linseed oil 
supplementation in the diet on the chemical and fatty acid composition of rainbow trout (Oncorhynchus mykiss W.), cultivated in recirculating system. Bulg. J. of Agric. Sci., Supplement 1, 21: 161-168, 2015.

12.Velichkova, K., Sirakov, I., Stoyanova, S., Biomass production and wastewater treatment from aquaculture with Chlorella vulgaris under different carbon sources. Scientific Bulletin. Series F. Biotechnologies, Vol. XVIII: 83-88, 2014.

13.Sirakov, I., Velichkova, K., Stoyanova, S., Staykov, Y., The importance of microalgae for aquaculture industry. Review. Intern. J. of Fisheries and Aquatic studies, 2(4):8184. 2015.

14.Stoyanova, S., Alternative Methods of Water Treatment for the Development of Sustainable Aquaculture. Review. Sci. J. of Ecol. and Environ., XIII(3): 54-58, 2014.

15.Commission Directive 2005/72/EC of 21 October 2005 amending Council Directive 91/414/EEC to include chlorpyrifos, chlorpyrifos-methyl, mancozeb, maneb, and metiram as active substances. Official $J$. of the Europ. Communities; L 279/63.

16.Tzanova, M., Atanasov, V., Zaharinov, B., Beev, G., Dinev, T., Valkova, E., Reproduction impact of mancozeb on rainbow trout (Oncorhynchus mykiss W.) and accumulation of its carcinogen metabolite, ethylene thiourea in fish products. J. of Central Europ. Agric., 18(2): 369-387, 2017.

17.Carpené, E., Gumiero, B., Fedrizzi, G., Serra, R., Trace elements in fish from rearing pounds of Emilia-Romagna region (Italy). Sci Total Environ., 141: 139-46, 1994.

18.Liang, Y., Cheung, R., Wong, M., Reclamation of wastewater from polyculture of freshwater fish: bioaccumulation of trace metals in fish. Water Res., 33(11): 2690-700, 2002.

19.Mansour, S. and Sidky, M., Ecotoxicological studies. 3. Heavy metals contaminating water and fish from Fayoum Governorate. Egypt. Food Chem., 78: 1522, 2002.

20.Beattie, J. and Pascoe, D., Cadmium uptake by rainbow trout, Salmo gairdneri eggs and alevins. J. Fish Biol., 13: 631-637, 1978.

21.Brauner, C. and Wood, C., lonoregulatory development and the effect of chronic silver exposure on growth, survival, and sublethal indicators of toxicity in early life stages of
VALKOVA E., et al. rainbow trout (Oncorhynchus mykiss). J. Comp. Physiol., B172: 153-162, 2002.

22.Buhl, K. and Hamilton, S., Relative sensitivity of early life stages of Artcic grayling, coho salmon and rainbow trout to nine inorganics. Ecotoxicol. Environ. Saf., 22: 184-197, 1992.

23.Dave, G.and Xiu, R., Toxicity of mercury, copper, nickel, lead, and cobalt to embryos and larvae of zebrafish, Brachydanio rerio. Arch. Environ. Contam. Toxicol., 21: 126134, 1991.

24.Davies, T., Pickard, J., Hall, K., Acute molybdenum toxicity to rainbow trout and other fish. J. Environ. Eng. Sci., 4: 481485, 2005.

25.Kazlauskiene, N. and Stasiunaite, P., The lethal and sublethal effect of heavy metal mixture on rainbow trout (Onchorynchus mykiss) in its early stages of development. Acta Zool. Lituanica Hydrobiol., 9 (2): 47 55, 1999.

26. Wedemeyer, G., Uptake and distribution of Zinc the Coho salmon egg (Oncorhynchus kisutch). Comp. Biochem. Physiol., 26,: 271-27, 1968

27.Westernhagen, H., Sublethal effects of pollutants on fish eggs and larvae. In: Hoar, W. S., Randall, D.J. (Eds.). Fish Physiol., vol. XIA, Academic Press, New York: 253346, 1988.

28. Crossgrov, J. and Zheng, G., Manganese toxicity upon overexposure, NMR Biomedicine, 17: 544-553, 2004.

29.Valkova, E., Comparative study of the levels of some heavy metals in the organism of heterotrophic hydrobiones from water bodies in Stara Zagora region. (dissertation), Stara Zahora, Faculty of Agriculture, Trakia University, Bulgaria, 2015. 249 p.

30. Velichkova, K., Sirakov, I., Valkova, E., Stoyanova, S., Kostadinova, G., Bioacumulation and protein content of Lemna minuta kunth and Lemna valdiviana phil. in bulgarian water reservoirs. Scientific Papers. Series E. Land Reclamation, Earth Observation \& Surveying. Environ. Engineering., Vol. VI, 1988, Print ISSN 2285-6064, CD-ROM ISSN 2285-6072, Online ISSN 2393-5138, ISSN-L 2285-6064: 104-107.

31.Atanasov, V., Staykov, Y., Mitev, M., Petkov, G., Dimanov, D., Miteva, Tsh., Bioenergy aspects of the embryogenesis of Salmo trutta m.fario $L$. as an ecological indicator for non-polluted water in the 
region. J. of Moun. Agric.on the Balkans, 2: 126-135, 1999a.

32.Atanasov, V., Mitev, J., Staykov, Y., Miteva, Tsh., Minchev, M., The bioenergy metabolism during embryogenesis of rainbow trout. Bulg. J. of Agric. Sci., 5: 917-922, 1999b.

33.Nakano, T., Kanmuri, T., Sato, M., Takeuchi, M., Effect of astaxanthin rich red yeast (Phaffia rhodozyma) on oxidative stress in rainbow trout. Biochim. et Biophys. Acta., 1426: 119-125, 1999.

34.Regulation № 44/2006, Veterinary requirements to the animal holdings. Bulgarian Ministry of Agriculture and Foods, Sofia, Bulgaria.

35.http://www.aqua-garant.com, AQUA GARANT FISH FEED - catalog.

36.Regulation 9/16.03.2001, Quality of water intended for drinking and household purposes. Bulgarian Ministry of Environment and Water, Sofia, Bulgaria.

37.Commission Directive 2000/60/EC of the European Parliament and of the Council of 23 October 2000 establishing a framework for Community action in the field of water policy. Official J. of the Europ. Communities, I. 327/1.

38.Tzanova, M., Quantification of Astaxanthin and Canthaxanthin in Muscle Tissues of Rainbow Trout /Oncorhynchus mykiss/ and Brook Trout /Salvelinus fontinalis/. Turkish Journal of Fisheries and Aquatic Sciences, 18: 1053-1061,2018, DOI: 10.4194/13032712-v18_9_05.
VALKOVA E., et al.

39. Tzanova, M., Accumulation of astaxanthin and canthaxanthin in muscle tissues of Rainbow trout (Oncorhynchus mykiss W.) fed with xanthophyll supplemented feed. Agric. Sci. and Technol., 9(1): 77-82, 2017 , DOI: 10.15547/ast.2017.01.013 77 - 82 .

40.Czeczuga, B., Carotenoids in fish. Salmonidae and Thymallidae from Polish water. Hydrobiologia, 46: 223-239, 1975.

41.Czeczuga, B., Carotenoids in fish. Clupeaharengus L. and Sprattussprattus L. (Clupeidae) of the Baltic Sea. Pol. Arch. Hydrobiol., 23: 123-129, 1976.

42.Svensson, P., Pélabon, C., Blount, J., Surai, P., Amundsen, T., Does female nuptial coloration reflect egg carotenoids and clutch quality in the Two-Spotted Goby (Gobiusculus flavescens, Gobiidae). Func. Ecology, 20: 689-698, 2006.

43.Pickova, J., Kiessling, A., Pettersson, A., Dutta, P., Fatty acid and carotenoid composition of eggs from two nonanadromous Atlantic salmon stocks of cultured and wild origin. Fish. Physiol. Biochem., 21: 147-156. 1999.

44.Bobe, J. and Labbé, C., Egg and sperm quality in fish. General and Comparative Endocrinology, 165, 535-548, 2010.

45. Regulation № 31/ 2004 for maximum levels of pollutants in food, State Gazette №88, 08.10.2004, amend. State Gazette, №51, 23.03.2006.

46.Regulation (EU) № 1881/ 2006. Setting Maximum Levels for Certain Contaminants in Foodstuffs. Official Journal of the European Union, L 364, 5. 